\title{
Statement by Miroslav Lajčák
}

\author{
President of the General Assembly of the United Nations at Its Seventy- \\ Second Session
}

Let me start by congratulating the International Law Commission on this landmark anniversary.

Over these past 70 years, 229 experts have given service of the highest quality. Each has contributed to making the Commission the unique success it has been. "Persons of recognized competence in international law"; 1 experts from various legal systems and all geographic regions; professionals with different skills lawyers, diplomats, academics, and jurists of the highest calibre. All working together despite differences. All working to achieve a common goal: the codification and progressive development of international law. I must, however, lament the limited number of women. It took 54 years before the first woman was elected. And even now only four of the 34 members are women. We must do better.

The Commission has contributed significantly to monumental pieces of work on many topics. The body of international law has become more robust. This is to the benefit of the people of the world. As we celebrate this occasion, I want to use the opportunity to make three points:

First, we must recognize the interface between the legal and the political. They are not at odds but complement each other. Both are essential for the success of the progressive development and codification of international law. In doing so we fulfil the mandate provided in the Charter.

The International Law Commission has helped to create many key international instruments. It is through the interaction between the legal and the political that the United Nations has made achievements in the international legal system. Debates in the Sixth Committee provide a way to foster this interaction. I welcome the efforts to streamline the dialogue between Committee and the Commission.

Further, the Commission's statute envisions an active role for States. Governments are invited to submit written comments to the Commission. We should make more use of this provision. It is important that such substantive input comes from all regions, groups and legal traditions.

Second, the ultimate beneficiaries are people. The United Nations exists for people. So too does the law. International law must continue to work both for

1 See article 2 of the ILC statute, UNGA Res 174(II) (21 November 1947) as amended by UNGA Res 485(v) (12 December 1950); Unga Res. 984(x) (3 December 1955); Unga Res 985(X) (3 December 1955) and UNGA Res $36 / 39$ (18 November 1981). 
States and for people. For example, there has been significant progress with respect to the development of international criminal law. We have avenues for the prevention, prosecution and punishment of most serious crimes. The Rome Statute ${ }^{2}$ and the International Criminal Court are the testimony of this achievement. The Commission was at the genesis of this process. ${ }^{3}$

I recently visited the Genocide Memorial in Rwanda. There I had the honour to make a $\$ 10,000$ contribution on behalf of the General Assembly. But what stood out was the lasting impact of that horrific period. The law failed to prevent; it failed to protect. People suffered and died. We said "never again" and we must live up to that promise.

It is encouraging to see the Commission's focus on crimes against humanity. In 1946, these crimes were prosecuted at Nuremberg. Today our focus must be on prevention. I encourage the Commission to maintain its momentum in this area. Atrocity crimes shock our collective conscience. Accountability, and strong rule of law, are key to preventing them.

My final point is on multilateralism. Here again, the Commission plays an indispensable role. The rule of law is the bedrock on which multilateralism is built. However, we must acknowledge the current context: multilateralism is under pressure. We need to strengthen it. Developing the law is crucial to doing so. This is what many of us as Member States depend on: a rules-based international order.

We have elaborated dozens of legal instruments over the past decades. Many have brought order and accountability. Many of them have prevented conflict. Others have supported development. As we identify new and emerging challenges, it is our duty to develop appropriate legal responses.

The International Law Commission is not a static body. Rather, it has made a mark both with codification and progressive development. It has contributed to 22 multilateral conventions and protocols and this work continues as one looks at uncharted territory. I encourage the Commission to forge ahead with developing international law. In doing so, the Commission helps to reinforce multilateralism.

The seventieth anniversary is good to reflect on the past, but it also offers a fitting opportunity to look to the decades ahead. I wish the Commission every success in its crucial work for years to come. On behalf of all "the peoples of these United Nations", I thank you.

2 Adopted 17 July 1998, entered into force 1 July 2002, 2187 UNTS 3.

3 See ILC, 'Draft Statute for an International Criminal Court, with commentaries' [1994] II(2)

ILC Ybk 26. 